Original Article

\title{
WINTERING RESERVE QUEENS IN MINI-PLUS AND 3-COMB NUCLEI
}

\author{
Maciej Siuda ${ }^{1}$ \\ Jerzy Wilde ${ }^{1^{*}}$ \\ Jerzy Woyke? \\ Zygmunt Jasiński \\ Beata Madras-Majewska² \\ ${ }^{1}$ Apiculture Division, Faculty of Animal Bioengineering, \\ Warmia and Mazury University, Sloneczna 48, 10-710 Olsztyn, Poland \\ 'Division of Apiculture, University of Life Science, \\ 166 Nowoursynowska, 02-787 Warsaw

\section{A bstract}

The aim of this study was to develop an effective method of overwintering reserve honey bee queens in two-storey mini-plus mating nuclei and in 3-comb nuclei (frames $36 \times 26 \mathrm{~cm}$, Wielkopolski hive). The assay was performed during three wintering seasons (2005 - 2008) parallel at two centers in Poland: the Division of Apiculture at the University of Life Sciences (SGGW) in Warsaw, and the Apiculture Division at the University of Warmia and Mazury (UWM) in Olsztyn.

The results showed that $59 \%$ of queens overwintered in mini-plus nuclei and $77 \%$ in 3 -comb nuclei. Among queens in mini-plus nuclei $63 \%$ overwintered in bee yard and only $55 \%$ in cellar. Within queens in 3 -comb nuclei, $62 \%$ overwintered in Olsztyn and $91 \%$ in Warsaw. The highest survival rate of $93 \%$ was observed in Warsaw during the first season. Due to low survival rate, it is not recommended to overwinter the queens in miniplus nuclei.

Keywords: honeybee queens, mini-plus nuclei, nuclei boxes, wintering.

\section{INTRODUCTION}

It is important to reduce losses in overwintering bee colonies. The availability of reserve honeybee queens in early spring can help to overcome these losses. Such queens can be introduced into colonies that have lost their own queens during the winter. They can also be introduced into early nuclei. Minimizing losses in overwintering colonies is particularly important in Poland because of its severe winters, cold springs, and short vegetative season. Therefore, an early import of queens from outside of Europe has raised a great interest among beekeepers (Wilde, 2006).

Instead of relying expensive imports, developing method of overwintering reserve queens could lead to a breakthrough in applied apicultural technologies.

Introducing a young queen stimulates the colony's dynamic development (Wilde, 2006). Fourfold increase of the queen's fertility brings about a six-fold increase in the colony's honey productivity (Farrar, 1968). According to Woyke (1984), honeybee colonies with 1 -year-old queens produced $27 \%$ more honey than those with 2-year-old queens. Akyol et al. (2008) report that approximately $71 \%$ and $41 \%$ less honey was harvested from colonies with 3-year-old queens than from colonies with 1- and 2-year-old queens, respectively. Honeybee colonies with young queens are also less likely to develop a swarming impulse (Siuda and Wilde, 2002; Wilde, 2006).

The first attempts to overwinter reserve queens were described by Griffin (1966) and Нагр (1967). Young queens were usually wintered in small nuclei (Maul and Schneider, 1990, 1991; Olejniczak, 2002; Siuda et al., 2011). Gencer (2003) reported success when overwintering queens in mating nuclei and in nuclei with five combs. Most tests were performed in a bee yard (Wyborn et al., 1993). Single queens were placed in the original hive, in a compartment composed of several combs, separated by 
a tight board (Bornus and Szymankiewicz, 1968). This method of wintering was not widely adopted because of high labor input and material costs.

Attempts were also undertaken to overwinter several queens in cages in so-called "queen banks" (Griffin, 1966; Harp, 1967). However, these queens were injured by antagonistic surrounding bees (Woyke, 1988; Jasiński, 1995). Attempts to winter freely moving queens deprived of their stings also failed (Paleolog, 2001). Efforts have been made to keep queens outside the hive during winter (Foti et al., 1962; Prabucki et al., 2003). However, no satisfactory results have been achieved.

Wintering queens in mating nuclei might be cheaper than importing queens if queen-rearing beekeepers had a great number of nuclei with egg-laying queens at their disposal in autumn. Previously, these nuclei with egg-laying queens had to be eliminated after the end of the breeding season (Büchler et al., 2013). The reasons mentioned above triggered the efforts to develop an effective method of overwintering reserve queens in mini-plus mating and in 3-comb nuclei.

\section{MATERIAL AND METHODS}

The assay was performed during the years 2005 2008 (three wintering seasons). It was conducted in parallel at two centers: the Division of Apiculture at the Warsaw University of Life Sciences (SGGW) in central Poland, and the Apiculture Division of the University of Warmia and Mazury in Olsztyn (UWM) in northeastern Poland.

We used different breeding queens each year at each center. Queens sisters of Apis mellifera carnica subspecies were reared in free-flying queenless starter colonies (Büchler et al., 2013). New sister queens were reared each year. Next they were instrumentally inseminated using the method described by Woyke et al. (2008). Experimental colonies were created after the queens started egg laying. The colonies were created in July and maintained in two types of nuclei: the multi-super mini-plus nucleus (MP) contained six combs in a box, with frames $215 \times 163 \mathrm{~mm}$. The Wielkopolski nucleus (WN) consisted of three combs in a 10-frame hive (frame size: $360 \times 260 \mathrm{~mm}$ ) divided into three parts, with tight hardboards. Attempts were made to develop strong colonies for wintering in two-storey MP nuclei (12 combs), and in WN nuclei in three combs. The winter feeding of the colonies started on 15 August and ended on 15 September each year. The colonies were fed syrup made of sugar and water in the ratio 5:3, until they achieved
6 - $7 \mathrm{~kg}$ winter store in MP and $5 \mathrm{~kg}$ in WN. In all, 174 colonies were overwintered.

\section{Creating colonies}

\section{Colonies in mini-plus nuclei}

The nuclei were stocked with three frames of foundation and approximately $250 \mathrm{~g}$ of Apis mellifera carnica worker bees (approximately 2500 bees). The nuclei were transferred to a dark cellar $\left(T=10^{\circ} \mathrm{C}\right)$ for two days. The established colonies were fed candy ad libitum. When temperatures fell below $0^{\circ} \mathrm{C}$ for a few consecutive nights, one-half of the colonies were transferred to a cellar $\left(T=4-5^{\circ} \mathrm{C}\right.$ and $\mathrm{RH}=65-75 \%$ ), while the remaining colonies were wintered in the bee yard. The MP colonies were returned to the bee yard in spring at the time when the first flight was expected.

At the SGCW Division of Apiculture in Warsaw, 14 MP nuclei were created during the 2005 - 2006 season alone; at the UWM Apiculture Division, a total of $52 \mathrm{MP}$ nuclei were created in all three experimental seasons. In all, 66 queens were wintered in MP nuclei.

\section{Colonies in 3-comb Wielkopolski nuclei}

Two combs with capped brood covered by worker bees (approximately 5000 insects) were removed from the Wielkopolski hive and placed in a nucleus (WN) to which another frame with foundation was added. After three days, egg-laying queens were introduced to the nuclei. The queens in WN colonies were wintered during the 2006 - 2007 and 2007 - 2008 seasons at both centers in a bee yard only. Fifty-four queens were wintered in each center. Altogether, we investigated the wintering of 108 queens.

The wintering colonies were examined with a stethoscope once each month. The course of wintering was assessed based on the emitted sounds. When sound assessment was difficult, the nucleus cover was lifted for a quick look at the colonies.

\section{Temperature and humidity}

Meteorological data were measured at the UWM meteorological station in Tomaszkowo near Olsztyn, and in the SGGW meteorological station in Ursynów in Warsaw. In 2005 - 2008 temperatures and humidity were measured during three seasons of each year, during the 6-month period from November until the following April. We received from the stations three averages of temperature and humidity for each particular month, except for the final month of the final year (April 2008), when we received only two averages. Altogether, we received 106 monthly average data for temperature and 106 monthly 
average data for humidity. The average daily air temperatures and humidity for Poland for the last 30 years were also obtained from the UWM meteorological station, and we refer to them as "perennial data".

\section{Disease}

Nosema spp. infestation of worker bees, which wintered in the three-comb nuclei in Olsztyn, was estimated in March 2007 and 2008, according to a previously described method (Fries et al., 2013).

\section{Statistics}

Two-factor ANOVA was used to determine the effect of the place of measurement (center) and of the year on the averages of temperature and humidity. Each monthly overall average for a particular season (Figs. 1, 2) was calculated from six averages (three averages from each of two centers). One-factor ANOVA was used to determine the significance of differences between the monthly overall differences in the three seasons (18 data averages), and Duncan's multiple test was applied to find significant differences between particular overall means in the three seasons.

The numbers of overwintered queens were estimated in April, when they could be used by the beekeepers. Those numbers were then transformed into percentages in relation to the total number of wintering queens. The percentage data were converted using the arcsine transformation (Bliss) for statistical calculations.

We used elementary ANOVA analysis to calculate the results of overwintering the colonies. According to Zee et al. (2013), this method ensures that the obvious characteristics of the data are clearly understood by readers of any resulting report. Two-factor ANOVA was performed. Significance of differences between the means was determined using Duncan's multiple range test. Calculations were performed using Statistica v. 10 software.

\section{RESULTS}

\section{Weather conditions}

Air temperature in three seasons

Two-factor ANOVA did not reveal any significant effect of the centers of investigation on the average air temperatures $\left(F_{1,100}=0.24\right.$, $p=0.628$ ). However, a significant effect of consecutive wintering seasons occurred $\left(F_{2,100}=9.27, p=0.0002\right)$. Interaction between the two factors was not found to be statistically significant $\left(F_{2,100}=0.06, p=0.944\right)$. Duncan's test showed that the average air temperature was significantly higher in November $2005\left(5.0^{\circ} \mathrm{C}\right)$ than in November 2007 (1.3ㄷ, Fig. 1). For December, the average air temperature was significantly higher in $2006\left(3.9^{\circ} \mathrm{C}\right)$ than in 2005 and $2007\left(-1.3^{\circ}\right.$ and $0.3^{\circ} \mathrm{C}$, respectively). For January, the average temperature was signifi-

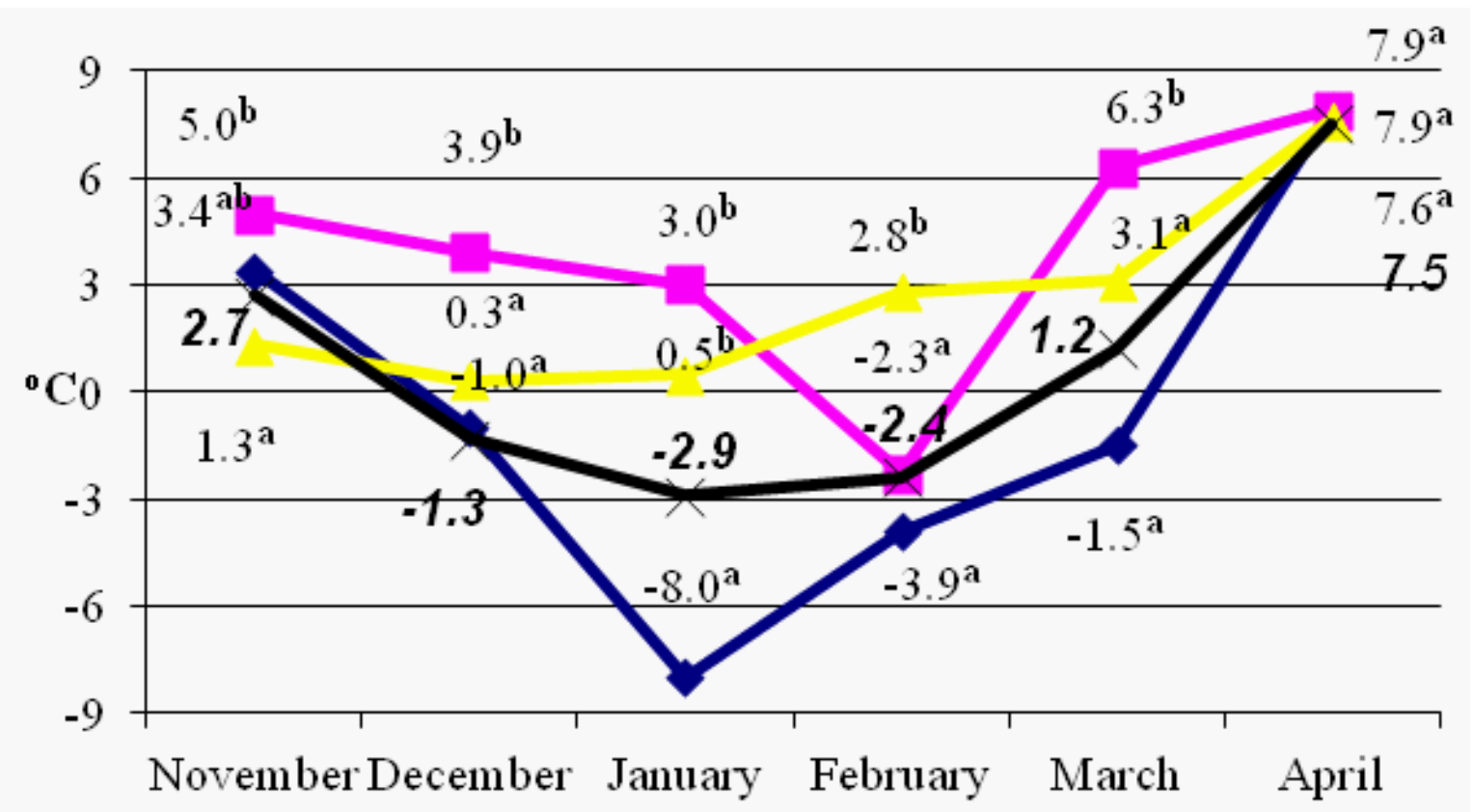

$2005 / 2006-2006 / 2007$ $2007 / 2008$ Perennial data

Fig. 1. Average monthly air temperatures during the experimental seasons $\left({ }^{\circ} \mathrm{C}\right)$. Different letters after means indicate significant differences in the monthly temperature between the seasons (Duncan's test, $p<0.05$ ). 


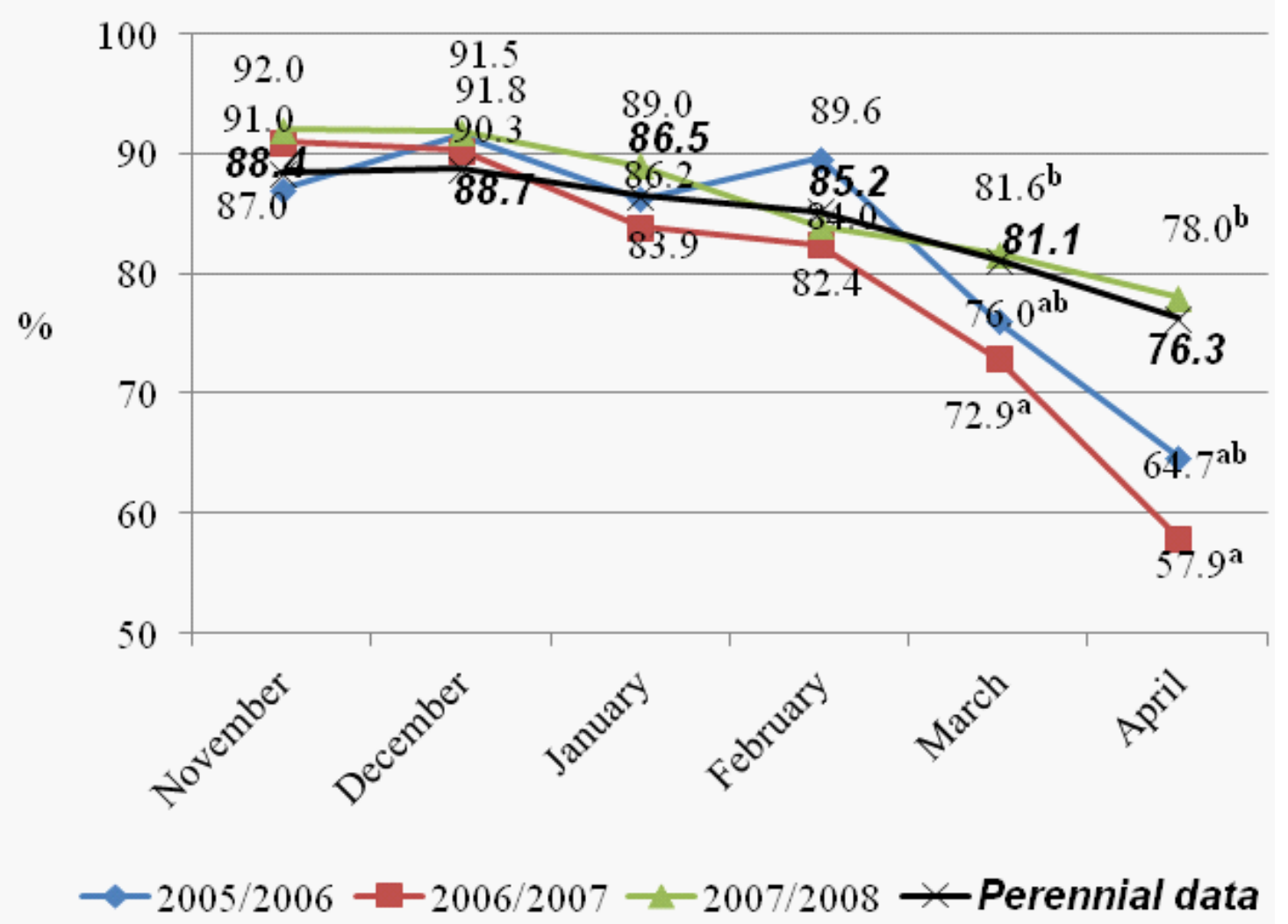

Fig. 2. The average monthly relative air humidity in experimental seasons (\%). No significant differences were observed for November through February. Different letters after means indicate significant differences in the monthly humidity between the seasons (Duncan's test, $p<0.05$ ).

cantly lower in $2006\left(-8.0^{\circ} \mathrm{C}\right)$ than in 2007 and 2008 $\left(3.0^{\circ} \mathrm{C}\right.$ and $0.5^{\circ} \mathrm{C}$, respectively). February 2006 and 2007 were characterized by average temperatures below zero $\left(-3.9^{\circ} \mathrm{C}\right.$ and $\left.-2.3^{\circ} \mathrm{C}\right)$; the average temperature in February 2008 was significantly higher $\left(2.8^{\circ} \mathrm{C}\right)$. The frost period during the 2005 - 2006 season lasted until March $\left(-1.5^{\circ} \mathrm{C}\right)$. March temperatures were during the two following seasons (2006 - 2007 and 2007 2008), higher and differed significantly between each other.

\section{Air humidity in three seasons}

Although relative humidity was not significantly affected by the centers $\left(F_{1100}=0.65, p=0.422\right)$, it was affected by the seasons $\left(F_{2,100}^{100}=3.47, p=0.035\right)$. Interaction between the two factors was not found to be statistically significant $\left(F_{2,100}=0.47, p=0.627\right)$. Duncan's test revealed that the average relative air humidity was comparable for the period from November to February in consecutive seasons $(82.4 \%$ - 92.0\%), and the means were not found to differ significantly (Fig. 2). In all seasons, humidity dropped during the spring. The average air humidity was significantly lower in March 2007 (72.9\%) than in March 2008 (81.6\%). The average air humidity was also significantly lower in April 2007 (57.9\%) than in April 2008 (78.0\%).

\section{Overwintering of reserve queens Overwintering of queens in two types of nuclei at both centers \\ Two-factor ANOVA showed a significant effect of the} centers where the nuclei were overwintered on the percentage of survivals $\left(F_{1,171}=6.95, p=0,009\right)$. However, it did not detect significant effect of the type of nuclei on the survival rate $\left(F_{1,171}=2.87\right.$, $p=0,092)$. Next the interaction between both factors was calculated. It appeared to be highly significant $\left(F_{1,170}=7.61, p=0.006\right)$. Surprisingly, taking into account the interaction, the effect of both factors on the survival was changed. Now, the effect of the centers was not found to be significant $\left(F_{1,170}=1.64\right.$, $p=0.203$ ). However, the effect of the type of nuclei appeared now to be significant $\left(F_{1,170}=7.32\right.$, $p=0.008$ ).

The survival of queens in Mini Plus nuclei was not found to differ significantly between the centers. However, a tendency of higher survival in Olsztyn (62\%), than in Warsaw (50\%) is visible (Tab. 1). Contrary, in Wielkopolski nuclei, significantly the highest percent of queens survived in Warsaw (93\%).

At both centers, significantly more queens survived winter in WN (77\%) than in MP (59\%) (Tab. 1). Significantly more queens survived in Warsaw (84\%) than in Olsztyn (61\%). 


\section{J. APIC. SCL. VOL. 58 NOV. 12014}

Overwintering of queens in mini-plus nuclei Overwintering of queens at two wintering sites

Two-factor ANOVA did not demonstrate any significant effects of the research centers $\left(F_{1,62}=1.40\right.$, $p=0.241)$, and the wintering site $\left(F_{1}{ }_{62}=2.30\right.$, $p=0.134)$, as well as the interaction $\left(F_{1,62}=2.30\right.$, $p=0.124)$ on the percentage of overwintered queens.

No statistically significant differences were noted regarding the percentages of queens that overwintered in the MP nuclei at different research centers or on different sites (bee yard or cellar) (Tab. 2). However, we note a tendency toward low survival of queens in the cellar in Warsaw (20\%).

\section{Overwintering of queens during three seasons}

Two-factor ANOVA did not demonstrate any significant effects of the season $\left(F_{2,60}=2.76\right.$, $\mathrm{p}=0.072)$, and the wintering site $\left(\mathrm{F}_{1,60}=0.76\right.$, $p=0.388)$, as well as of the interaction $\left(F_{2,60}=0.75, p=0.476\right)$ on the percentage of overwintered queens. The effect of the season ( $p=0.07)$ neared statistical significance ( $p=0.05)$. Ostensibly, this is why Duncan's test showed significant differences between the seasonal overall means $(p<0.05)$. However, no significant difference was between the overall survival rates at both sites (bee yard or cellar).

Duncan's test revealed statistically significant differences between the six mean percentages of queens that overwintered in MP nuclei in the three experimental seasons on the two sites (Tab. 2). The lowest percentage of queens (22\%) overwintered in a cellar during the 2005 - 2006 seasons. Significantly greater percentages (67\% - 70\%) overwintered at both sites (the bee yard and the cellar) during two next seasons (2006 - 2008).

\section{Overwintering of queens in Wielkopolski nuclei at the bee yard}

Two-factor ANOVA demonstrated significant effect of the research centers on the percentage of queens that overwintered in $W N\left(F_{1,104}=12.74, p=0.0005\right)$. However, it did not demonstrate significant effects of the seasons $\left(F_{1,104}=2.56, p=0.113\right)$ or the interaction between the two factors $\left(F_{1,104}=0.33\right.$, $p<0.564)$. The last result indicates that the percentages of surviving queens were similar in both centers during both seasons.

The lowest percentages of queens overwintered in Olsztyn during the first (71\%) and second (53\%) season (Tab. 3). Significantly, the highest percentage of queens survived the winter during the first season in Warsaw (95\%). The overall seasonal survival at both centers was not found to differ significantly between the first season (83\%) and the second season (70\%). During both seasons, significantly ca. 1.5 -fold more queens overwintered in Warsaw (91\%) than in Olsztyn (62\%) (Tab. 3). On average, $76 \%$ of queens overwintered in WN during two seasons at both centers.

\section{DISCUSSION}

On average, $70 \%$ of queens overwintered in two-storey mini-plus and in three-comb nuclei (Tab. 1). The survival rates differed at the two research centers. Approximately 1.4-fold more queens overwintered in Warsaw than in Olsztyn (84\% vs. 61\%). Successful wintering is significantly affected by atmospheric conditions, especially by the number of days with severe frost, as well as by thaw. Particularly low temperatures occurred during the 2005 - 2006 winter season, reaching as low as $-26^{\circ} \mathrm{C}$, which reduced the percentage of queens that overwintered in MP nuclei in the bee yard to $54 \%$

Table 1.

The percentage of queens that overwintered at two research centers in two types of nuclei

\begin{tabular}{ccccccc}
\hline \multirow{2}{*}{ Center } & \multicolumn{4}{c}{ Nucleus type } & \multirow{2}{*}{ Centers overall } \\
\cline { 2 - 5 } & \multicolumn{3}{c}{ Mini Plus } & \multicolumn{2}{c}{ Wielkopolski } & \\
\cline { 2 - 5 } & $\mathrm{n}$ & $\% \pm \mathrm{SD}$ & $\mathrm{n}$ & $\% \pm \mathrm{SD}$ & $\mathrm{n}$ & $\% \pm \mathrm{SD}$ \\
\hline Warsaw & 14 & $50^{\mathrm{a}} \pm 12.5$ & 54 & $93^{\mathrm{b}} \pm 3.2$ & 68 & $84^{\mathrm{D}} \pm 4.0$ \\
\hline Olsztyn & 52 & $62^{\mathrm{a}} \pm 6.1$ & 54 & $61^{\mathrm{a}} \pm 6.0$ & 106 & $61^{\mathrm{C}} \pm 4.3$ \\
\hline Nuclei overall & 66 & $59^{\mathrm{A}} \pm 5.5$ & 108 & $77^{\mathrm{B}} \pm 3.7$ & 174 & $70 \pm 3.1$ \\
\hline
\end{tabular}

Different superscript letters after means indicate significant differences between them (Duncan, $p<0.05$ ). Lower-case superscript letters concern individual combinations of center $\times$ nuclei (four means). Capital superscripts $A$ and $B$ concern overall means of different nucleus types (within the same line), and $C$ and $D$ concern overall means within the same column. All of the data concern original values, however, statistical calculations were performed on transformed values. 
(Tab. 2). Other researchers have also observed an effect of temperature on the success of overwintering reserve queens in nuclei (Prabucki et al., 2003; Siuda et al., 2011). Sowa et al. (1983) wintered their colonies indoors at approximately $4^{\circ} \mathrm{C}$, and reported survival rate of $93-95 \%$.

Air humidity also affects the effectiveness of queens' wintering. High air humidity shortens the life of wintering bees (Nerum and Buelens, 1997). In our assay, an average of $55 \%$ of colonies kept in MP nuclei overwintered in a cellar at approximately $4^{\circ} \mathrm{C}$ (Tab. 2). The high air humidity (RH 95 - 100\%) in the cellar in Olsztyn during the 2005 - 2006 season reduced the overwintering of queens to only $22 \%$.
Reducing humidity to RH 65 - 75 by using extra air-drying equipment during the next two seasons increased the survival of queens in MP nuclei in the cellar to $70 \%$ and $67 \%$.

The strength of the nuclei and the quality of the worker bees are important factors for the overwintering of reserve queens. Siuda et al. (2011) reported that in the Polish climate only $2 \%$ of queens overwintered in small, trapezoid, top-bar mating nuclei in a bee yard or in a cellar. However, Maul and Schneider (1991) were able to overwinter $45-83 \%$ of queens in similar nuclei in a cellar by refilling the nuclei with winter bees from healthy colonies once each season. Bornus and Szymankie-

The percentage of queens that overwintered in mini-plus nuclei at two centers during three seasons

\begin{tabular}{|c|c|c|c|c|c|c|}
\hline \multirow{3}{*}{ Centers } & \multicolumn{4}{|c|}{ Wintering site } & \multirow{2}{*}{\multicolumn{2}{|c|}{ Centers overall }} \\
\hline & \multicolumn{2}{|c|}{ Bee yard } & \multicolumn{2}{|c|}{ Cellar } & & \\
\hline & $n$ & $\% \pm S D$ & $n$ & $\% \pm S D$ & $n$ & $\% \pm S D$ \\
\hline Warsaw & 9 & $67 \pm 16.5$ & 5 & $20 \pm 22.1$ & 14 & $50 \pm 13.8$ \\
\hline Olsztyn & 26 & $62 \pm 9.7$ & 26 & $62 \pm 9.7$ & 52 & $62 \pm 6.8$ \\
\hline $\begin{array}{c}\text { Wintering sites } \\
\text { overall }\end{array}$ & 35 & $63 \pm 9.5$ & 31 & $55 \pm 12.1$ & 66 & $59 \pm 6.1$ \\
\hline Seasons & & & & & & ns overall \\
\hline $2005-2006$ & 13 & $54^{\mathrm{ab}} \pm 5.2$ & 9 & $22^{\mathrm{a}} \pm 4.4$ & 22 & $41^{A} \pm 5.0$ \\
\hline $2006-2007$ & 10 & $70^{\mathrm{b}} \pm 4.8$ & 10 & $70^{b} \pm 4.8$ & 20 & $70^{c} \pm 4.7$ \\
\hline $2007-2008$ & 12 & $67^{b} \pm 4.9$ & 12 & $67^{b} \pm 4.9$ & 24 & $67^{\mathrm{BC}} \pm 4.8$ \\
\hline $\begin{array}{c}\text { Wintering sites } \\
\text { overall }\end{array}$ & 35 & $63^{A} \pm 4.9$ & 31 & $55^{A} \pm 5.1$ & 66 & $59 \pm 6.1$ \\
\hline
\end{tabular}

Superscript letters indicate significant differences $(p<0.05)$. Lower-case superscript letters concern individual combinations of wintering sites $\times$ seasons (six means), capital $A$ concerns overall means within the same line (wintering sites), and means denoted with capitals B and C concern overall means within the same column (seasons).

Table 3.

The percentage of queens that overwintered in Wielkopolski nuclei (WN) at both research centers during both seasons

\begin{tabular}{cccccccc}
\hline \multirow{2}{*}{ Center } & \multicolumn{4}{c}{ Season } & \multicolumn{2}{c}{ Centers overall } \\
\cline { 2 - 5 } & \multicolumn{3}{c}{$2006-2007$} & & $2007-2008$ & & \\
\cline { 2 - 5 } & $\mathrm{n}$ & $\% \pm \mathrm{SD}$ & $\mathrm{n}$ & $\% \pm \mathrm{SD}$ & $\mathrm{n}$ & $\% \pm \mathrm{SD}$ \\
\hline Warsaw & 39 & $95^{\mathrm{c}} \pm 3.2$ & 15 & $87^{\mathrm{bc}} \pm 8.2$ & 54 & $91^{\mathrm{c}} \pm 3.2$ \\
\hline Olsztyn & 24 & $71^{\mathrm{b}} \pm 8.5$ & 30 & $53^{\mathrm{a}} \pm 8.3$ & 54 & $62^{\mathrm{B}} \pm 6.0$ \\
\hline Seasons overall & 63 & $83^{\mathrm{A}} \pm 4.0$ & 45 & $70^{\mathrm{A}} \pm 6.5$ & 108 & $76 \pm 3.7$
\end{tabular}

Different superscript letters after means indicate significant differences (Duncan, $p<0.05$ ). Lower-case superscript letters concern four means of individual combinations of seasons $x$ centers. Capital superscript A concerns overall means in the same line (seasons), and capital superscripts B and C concern overall means in the same column (centers). 
wicz (1968) overwintered $50 \%$ of queens in nuclei located between two colonies in one hive in a bee yard. In such conditions, bees in the nuclei were heated by the neighboring colonies. According to Siuda et al. (2011), wintering strong colonies on six combs in mini-plus nuclei instead of weak ones on three combs increased the survival 1.4-fold, from $30 \%$ to $41 \%$.

In our assay, $63 \%$ and $55 \%$ of queens survived in two-storey mini-plus nuclei on 12 combs in a bee yard or in a cellar, respectively. This result is from 1.3-fold to 1.5-fold more than was reported by Siuda et al. (2011) for wintering in one-storey (six combs) MP. Wintering conditions in stronger colonies are more favorable for the wintering bees.

Gencer (2003) overwintered $16.7 \%$ of queens in screen cages and $40.5 \%$ in partitioned combs $(4 \times$ $4 \mathrm{~cm}$ ) in queenless colonies in Turkey. However, as many as $80.0 \%$ of queens overwintered in Kirchainer mating nuclei and $83.3 \%$ in five-comb Langstroth nuclei. Levinsohn and Lensky (1981) stored successfully $80 \%$ of queens for more than 5 months in queenless reservoir colonies in a subtropical climate. Bornus and Szymankiewicz (1968) overwintered $96 \%$ of queens in three-comb nuclei, with a frame of half-Dadant size, placing four nuclei in one hive box. In our assay, an average of $77 \%$ of queens overwintered in three-comb nuclei. However, while as many as $93 \%$ of queens overwintered in Warsaw, only $61 \%$ survived in Olsztyn. The Warsaw result is similar to that achieved by Bornus and Szymankiewicz (1968). In Olsztyn, the low survival rate was ostensibly caused by a strong Nosema sp. invasion. Nosema sp. spores were found in all bee samples collected from the collapsed colonies in Olsztyn, and in only $27 \%$ samples collected from three-comb colonies that survived.

\section{CONCLUSIONS}

1. The wintering of queens in three-comb nuclei with three units placed in a 10-comb Wielkopolski hive may be successfully performed in the environmental conditions of Poland ( $77 \%$ overwintered queens). 2. Wintering queens in mini-plus nuclei with a super in a bee yard (63\%) or in a cellar (55\%) is not recommended due to low survival rate.

\section{ACKNOWLEDGEMENTS}

The assay was performed with support from the Ministry of Science and Higher Education (Research Project No 2 P06Z 058 28).

\section{REFERENCES}

Akyol E., Yeninar H., Korkmaz A., Cakmak I. (2008) An observation study on the effects of queen age on some characteristics of honey bee colonies. Italian Journal of Animal Science 7: 19-25.

Bornus L., Szymankiewicz J. (1968) Porównawcze badania nad zimowaniem zapasowych matek pszczelich. Pszczelnicze Zeszyty Naukowe 12: 31-41.

Büchler R., Andonov S., Bienefeld K., Costa C., Hatjina F. Kezic N., Kryger P., Spivak M., Uzunov A., Wilde J. (2013) Standard methods for rearing and selection of Apis mellifera queens. In: Dietemann V., Ellis J. D., Neumann P. (Eds.) The COLOSS BEEBOOK, Volume l: standard methods for Apis mellifera research. Journal of Apicultural Research 52: 1-29. D0l:10.3896/IBRA.1.52.1.07.

Farrar C. L. (1968) Productive management of honeybee colonies. American Bee Journal 108: 316-317.

Foti N., Barac l., Alexandru V., Mirza E. (1 962) Untersuchungen über die Überwinterung von Weiseln ausserhalb der Traube und ihre Verwendung innerhalb der Produktion. Archiv für Geflügel- und Kleintierzucht 11: 340360.

Fries I., Chauzat M-P., Chen Y-P., Doublet V., Genersch E., Gisder S., Higes M., Mcmahon D. P., Martín-Hernández R., Natsopoulou M., Paxton R. J., Tanner G., Webster T. C., Williams G. R. (2013) Standard methods for nosema research. In: Dietemann V., Ellis J. D., Neumann P. (Eds.) The COLOSS BEEBOOK: Volume Il: Standard methods for Apis mellifera pest and pathogen research. Journal of Apicultural Research 52: 1-28. DOl:10.3896/IBRA.1.52.1.14

Gencer H. V. (2003) Overwintering of honey bee queens en mass in reservoir colonies in a temperate climate and its effect on queen performance. Journal of Apicultural Research 42: 61-64.

Griffin L. A. M. (1 966) Advances made with queen banks in Soth Island. New Zealand Journal of Agriculture 113 : 41.

Harp E. R. (1967) Storage of queen bees. American Bee Journal 107: 250-251.

Jasiński Z. (1 995) Uszkodzenia matek pszczelich w czasie ich przechowywania. Rozprawy Naukowe i Monografie. Wydawnictwo SCCW. 56 pp. 
Levinsohn M, Lensky Y. (1981) Long-term storage of queen honeybees in reservoir colonies. Journal of Apicultural Research 20: 226-233.

Maul V., Schneider H. (1990) Ablegerbildung im Herbst aus winterfertigen Völkern zur Überwinterung von Reserveköniginen. Die Biene 126: 632-637.

Maul V., Schneider H. (1991) Überwinterung von Reserveköniginen im Kirchhainer Begattungskastchen (KBK). Die Biene 127:61-68.

Nerum van K., Buelens H. (1997) Hypoxia-Controlled winter metabolism in honeybees (Apis mellifera). Comparative Biochemistry and Physiology. Part A: Physiology 117: 445-455.

Olejniczak R. (2002) Zimowanie matek zapasowych w małych rodzinach. Pszczelarstwo 53: 19. Available at: http://jerzy_woyke.users.sggw.pl/R.Olejniczak.pdf

Paleolog J. (2001) An attempt at overwintering stingclipped queens in multiple-queen colonies. Journal of Apicultural Science 45: 13-20.

Prabucki J., Samborski J., Chuda-Mickiewicz B. (2003) Experiment on storing bee queens over the winter outside the hive. Journal of Apicultural Science 47: 39-46.

Siuda M., Wilde J. (2002) Racjonalne rozmnażanie rodzin skutecznie zwalcza nastrój rojowy i zwiększa produkcyjność rodzin. Biuletyn Naukowy UWM 18: $27-$ 34.

Siuda M., Wilde J., Bratkowski J., Chuda-Mickiewicz B. Woyke J., Jasiński Z., Madras-Majewska B., Samborski J. (2011) Wintering queens in modified mating nuclei. Journal of Apicultural Science 55: 87-98.
Sowa S., Jagiełło R., Woźnica J. (1983) Zimowanie zapasowych matek w rodzinkach weselnych w pomieszczeniu zamkniętym. In: Proceedings of XX Naukowa Konferencja Pszczelarska. 23-25 marzec Puławy: 20. Available at: http://jerzy_woyke.users.sggw.pl/S.Sowa.pdf

\section{Statistica v 10 (2013). StatSoft Inc.}

Wilde J. (2006) Czy polskiemu pszczelarstwu potrzebny jest import matek pszczelich wczesną wiosną? Pszczoły PL, portal o pszczelarstwie. Available at: www.pszczoly. pl/jerzy_wilde/jerzy_wilde3.php.

Woyke J. (1984) Correlations and interactions between population, length of worker life and honey production by honeybees in temperate region. Journal of Apicultural Research 23: 148-154.

Woyke J. (1988) Problems with queen banks. American Bee Journal 128: 276-278.

Woyke J., Jasiński Z., Prabucki J., Wilde J., Chuda-Mickiewicz B., Siuda M., Madras-Majewska B., Samborski J., Bratkowski J., Jojczyk A. (2008) Onset of oviposition by honey bee queens, mated either naturally or by various instrumental insemination methods, fits a lognormal distribution. Journal of Apicultural Research 47(1): 1-9.

Wyborn M. H., Winston M. L., Laflamme P. H. (1993) Storing mated queens during the winter in managed honey bee colonies. American Bee Journal 133: 201-205.

Zee van der R., Gray A., Holzmann C., Pisa L., Brodschneider R., Chlebo R., Coffey M. F., Kence A., Kristiansen P., Mutinelli F., Nguyen B. K., Noureddine A., Peterson M., Soroker V., Topolska G., Vejsnæs F., Wilkins S. (2013) Standard survey methods for estimating colony losses and explanatory risk factors in Apis mellifera. Journal of Apicultural Research 52: 1-35. DOl:10.3896/IBRA.1.52.4.18. 